\title{
Decimal Ratio
}

National Cancer Institute

\section{Source}

National Cancer Institute. Decimal Ratio. NCI Thesaurus. Code C67272.

A ratio expressed in base 10 notation. 